\title{
Reproductive biology of Perkinsiana antarctica (Kinberg) (Polychaeta, Sabellidae) in the Straits of Magellan (South America): Systematic and ecological implications*
}

\author{
MARIA CRISTINA GAMBI and FRANCESCO PAOLO PATTI \\ Stazione Zoologica “Anton Dohrn”, Laboratorio di Ecologia del Benthos, Punta S. Pietro, I-80077 Ischia (Napoli) Italy. \\ E-mail: gambimc@alpha.szn.it
}

\begin{abstract}
SUMMARY: Reproductive biology and larval development of the polychaete Perkinsiana antarctica (Kinberg, 1867) (Sabellidae) are described of a population sampled in October 1994 and March 1997 in the type locality of this species, the Straits of Magellan (Southern Chile). Perkinsiana antarctica is a simultaneous hermaphrodite. Eggs are present in the thorax and in the anterior part of the abdomen, while sperm cells occur in the posterior abdomen. Spermatids are grouped in tetrads; mature sperm cells present an oval nucleus (length of major axis about $3 \mu \mathrm{m}$ ) and the acrosome is about $2.5 \mu \mathrm{m}$ long with a conoid shape. Mature eggs have a mean diameter of $235 \mu \mathrm{m}$; embryos and larvae are incubated within the branchial crown of specimens exceeding $10 \mathrm{~mm}$ in length. Hatching larvae have a mean length of $420 \mu \mathrm{m}$, with 4 segments, each bearing two notochaeta; two ocular spots and a well-developed prototroch are present at the anterior end. Both number of embryos and larvae per individual showed a relatively high range of variation (embryos from 54 to 374, mean=173; larvae from 18 to 222, mean=101). The features of reproductive biology in $P$. antarctica do not seem to be related to the size of the species itself, as $P$. antarctica represents one of the largest-sized sabellids that are brooding eggs, and producing a relatively high number of offspring. These reproductive and developmental traits seem more related to the colonization of harsh and selective habitats, such as the intertidal and shallow subtidal of the Subantarctic areas. Comparisons with the reproductive biology of other species of Perkinsiana demonstrate a high degree of variability within the genus regarding reproduction and the apparent lack of synapomorphies.
\end{abstract}

Key words: Polychaeta, Sabellidae, reproductive biology, larval development, Subantarctic, Chile.

RESUMEN: Biología Reproductiva de Perkinsiana antarctica (KinBerg) (Polychaeta, Sabellidae) en el estrecho de MAGALLANES (AMÉRICA DEL SUR): IMPLICACIONES SISTEMÁTICAS Y ECOLÓGICAS. - Se describe la biología reproductiva y el desarrollo larvario del poliqueto Perkinsiana antarctica (Kinberg, 1867) (Sabellidae) en una población muestreada en octubre de 1994 y marzo de 1997 en su lugar tipo, el Estrecho de Magallanes (Chile meridional). P. antartica es un hermafrodita simultáneo. Los huevos se sitúan en el tórax y en la zona anterior del abdomen, mientras que las células espermáticas se encuentran en la parte posterior de éste. Las espermátidas están agrupadas en tetradas; las células espermáticas maduras presentan un núcleo oval (longitud del eje mayor aproximadamente de $3 \mu \mathrm{m}$ ) y un acrosoma de forma cónica con una longitud cercana a los $2,5 \mu \mathrm{m}$. Los huevos maduros poseen un diámetro de $235 \mu \mathrm{m}$; para aquellos individuos que superan los $10 \mathrm{~mm}$ de longitud los embriones y las larvas se incuban en el interior de la corona branquial. El primer estadio larvario presenta larvas de cuatro segmentos con una longitud media de 420 um, cada segmento presenta dos notosedas; en el extremo anterior se encuentran presentes dos manchas oculares y una bien desarrollada prototroca. El número de embriones y larvas muestran un amplio rango de variación (embriones desde 54 a 374 , media $=173$; larvas desde 18 a 222, media=101). Las características de la biología reproductiva de $P$. antartica parecen no relacionarse con la talla intrínseca de la especie, ya que ésta posee una de las mayores tallas dentro del grupo de los sabélidos que incuban los huevos, y produce un número de descendientes relativamente alto. Estas características parecen más bien relacionarse con la colonización de hábitats muy extremos y selectivos, como por ejemplo el intermareal y submareal poco profundo de las áreas subantárticas. La comparación de la biología reproductiva de esta especie con otras del genero Perkinsiana demuestra un alto grado de variación dentro del género y una falta de synapomorfias.

Palabras clave: Poliquetos, Sabellidae, biología reproductiva, desarrollo larvario, región subantártica, Chile.

*Accepted July 21, 1998. 


\section{INTRODUCTION}

The main traits of the reproductive biology and larval development of marine invertebrates are often correlated with the environmental features, especially in extreme climatic conditions (e.g., polar regions) or harsh habitats (e.g., intertidal). However, also in these situations, adult size and phylogenetic constraints play an important role (Giangrande et $a l ., 1994)$. Their influence has been shown also for Antarctic regions (Pearse et al., 1991) where many invertebrates are reported to brood eggs or to have lecitotrophic or direct development to overcome the adverse and oligotrophic conditions of the water column during the winter season. While this pattern, as well as the latitudinal gradient of larval development, is still recognizable in prosobranch molluscs (Thorson's rule) (Pearse et al., 1991), in other invertebrates brooding or lecitotrophy seem more phylogenetically related, as in crustacean peracarids or ophiuroids, or constrained by size, as in some polychaetes (Pearse et al., 1991). Recently, the role of preadaptation due to phyletic relationships has been shown also in relation to depth distribution of polar marine invertebrates (Brey et al., 1996).

Comparative data on closely related species (within the same genus or family) may therefore help to understand the relative importance and influence of phylogeny, size, and environment on the reproductive features of polar organisms. Within this framework we present some data on reproductive biology and larval development of the polychaete Perkinsiana antarctica (Kinberg, 1867) (Sabellidae), a species common in the intertidal and shallow subtidal biotopes of various Subantarctic regions (Giangrande and Gambi, 1997). The species is characterized by brooding of eggs and larvae within the branchial crown, which has been described from scarce museum specimens (Knight-Jones and Bowden, 1984). The aim of this study is to provide more detailed and comparative observations on reproductive biology and larval development of $P$. antarctica, based on the analysis of a population collected in the Straits of Magellan (Southern Chile), which represents the type locality of this species.

The genus Perkinsiana was established to encompass several species previously assigned to Potamilla Malmgren, 1865, and Potamethus Hartman, 1969. As pointed out by Fitzhugh (1989), Perkinsiana is not definable by any synapomorphy. According to Fitzhugh the genus resembles Potamilla and Potaspina in having elongate, broad- ly hooded abdominal setae. The most common sabellid reported from the Southern Ocean is Perkinsiana antarctica which was established by Kinberg (1867) as Laonome antarctica from the Straits of Magellan. The redescription of the species by Knight-Jones (1983) was based on the analysis of Ehlers's material from the Beagle Channel. Ehlers had Kinberg's material (holoptype) for comparison, but that material seems to be lost (Knight-Jones, 1983). Thus, the finding of $P$. antarctica in the type locality allowed the description of the neotype of the species (Giangrande and Gambi, 1997).

The records of $P$. antarctica from Antarctic and Subantarctic areas are extensive, and often reported as Potamilla antarctica (see Giangrande and Gambi, 1997 for literature). Previous findings indicate often that the species shows a wide depth distribution and a high degree of morphological variability. A recent revision of the genus Perkinsiana in Antarctica (Giangrande and Gambi, 1997), lead to the recognition of three different species that have been often confused with $P$. antarctica: P. littoralis (Hartman), P. milae Giangrande and Gambi, and P. borsibrunoi Giangrande and Gambi. While P. milae sems to be restricted to the Ross Sea, the other two species occur in various Antarctic and Subantarctic zones, are larger than P. antarctica and live in deeper bottoms (Giangrande and Gambi, 1997). The "true" $P$. antarctica seems restricted to the intertidal and shallow subtidal habitats of the Subantarctic areas (Giangrande and Gambi, 1997).

\section{MATERIAL AND METHODS}

The material studied was collected in October 1994 during the joint Chilean-German-Italian campaign in the Straits of Magellan named "Victor Hensen" (Arntz and Gorny, 1996). The population of $P$. antarctica was found along the Chilean Patagonian coasts of the Straits of Magellan, at Bahía Laredo located about $25 \mathrm{~km}$ north of the city of Punta Arenas. The worms were sampled, by SCUBA diving, in quantitative samples obtained scraping the surface and removing all pebbles and small stones inside of a quadrate (side $30 \mathrm{~cm}$ corresponding to a surface of $900 \mathrm{~cm}^{2}$ ) along a depth gradient from the upper tidal level to $3 \mathrm{~m}$ depth (Gambi et al., 1996). All collected specimens were fixed in $4 \%$ formaldehyde and preserved in $70 \%$ ethanol. Supplementary specimens were obtained from benthic material collected at the beginning of March 
1997 by scientists of the Instituto de la Patagonia, always by SCUBA diving at Bahía Laredo, and at depths between $0.5 \mathrm{~m}$ and $2 \mathrm{~m}$ (E. Mutschke, pers. comm.).

A detailed morphological description of the species can be found in Knight-Jones (1983), and in particular for the specimens analyzed for this study in Giangrande and Gambi (1997).

The presence of developing eggs (embryos) or larvae within the branchial crown was checked in all the individuals sampled both in 1994 and 1997, while their number was counted from 17 brooding specimens (12 with embryos and 5 with larvae) collected in 1994. On a random subsample of 108 specimens collected in 1994, a biometric analysis was performed to study both allometric relationships and population structure (size-frequency distribution). Number of thoracic segments, body and crown lengths, as well as width of the 2nd segment and wet
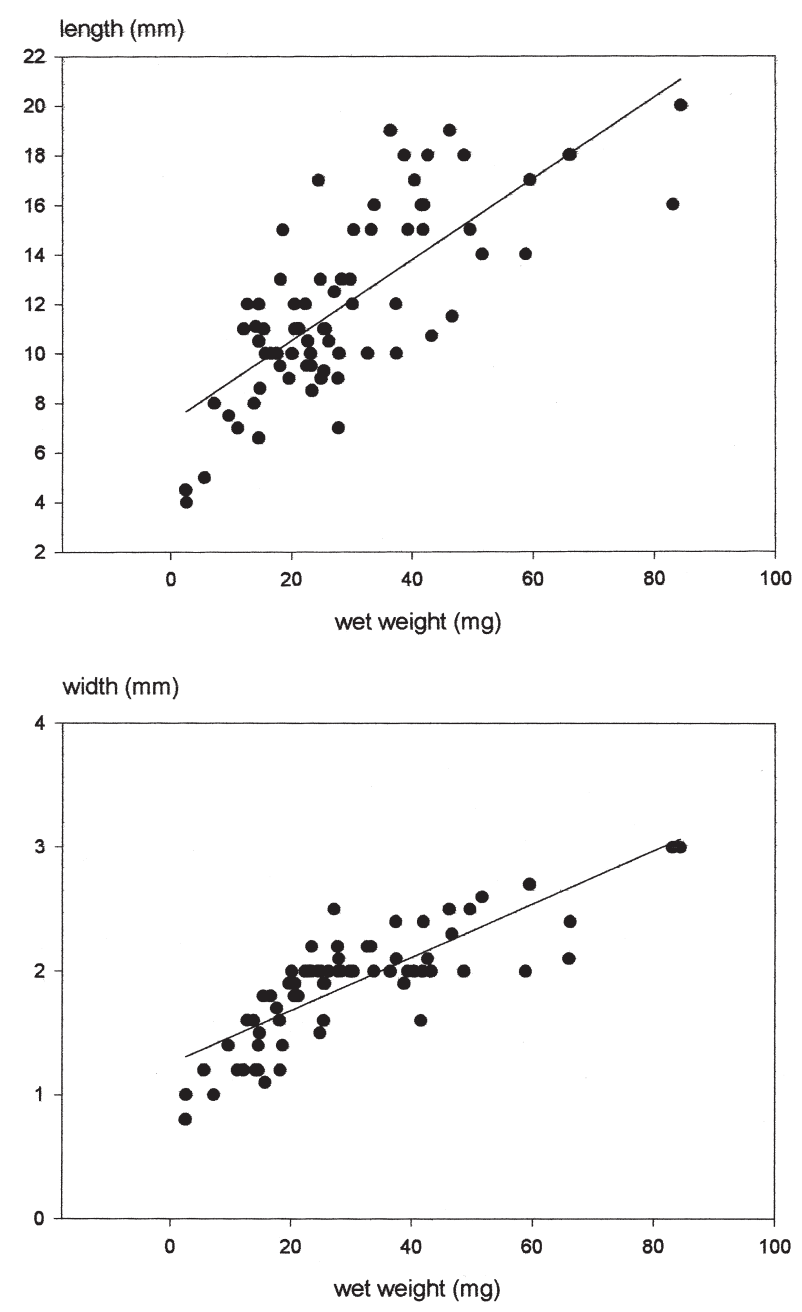

FIG. 1. - Relationships between body length (crown excluded) and wet weight (A) $(\mathrm{N}=73, \mathrm{r}=0.75, \mathrm{P}<0.01, \mathrm{Y}=-12.33+(3.45 \mathrm{X})$ ), and between body width and wet weight $(\mathrm{B})(\mathrm{N}=73, \mathrm{r}=0.80, \mathrm{P}<$ $0.01, \mathrm{Y}=1.25+(0.02 \mathrm{X}))$. weight were measured. Wet weight was estimated in ethanol preserved material by weighing each single specimen after 2 minutes drying in blotting paper. The measured parameters were tested in pairs for linear correlation analysis. For the specimens collected in 1997 only body length was measured.

Eggs and larvae were observed with an optical microscope, and were measured with a micrometer; sperm cells and some larvae were observed at the scanning electron microscope (S.E.M.). The material for S.E.M. analysis was dehydrated in ethanol, critical-point-dried with $\mathrm{CO}_{2}$ and coated with carbon and gold before viewing with a Philips 505 instrument.

\section{RESULTS}

A total of 355 specimens of $P$. antarctica were sampled in 1994; worms were particularly abundant at $2 \mathrm{~m}$ depth in a bottom characterized by sand and pebbles, and colonized by the brown macroalga Macrocystis pyrifera (kelp). Most of the specimens were attached with their tubes to pebbles and small stones, or to the holdfasts of Macrocystis. A total of 46 specimens were sampled in March 1997 at a similar depth range and environment (E. Mutschke, pers. comm.).

As for the biometric analysis, the number of thoracic segments was constantly 8 regardless of size; body length varied between 2.7 and $25 \mathrm{~mm}$, crown length between 2 and $8 \mathrm{~mm}$, and width between 0.08 and $3 \mathrm{~mm}$. Wet weight ranged from 2.06 to $84.4 \mathrm{mg}$. Body length and width were both positively and significantly correlated with wet weight (Fig. 1a and 1b) $(r=0.75, P<0.01$ length vs weight; $r=080, P<$ 0.01 width vs weight; for the other parameters see legend of Fig. 1). Body length and width showed a lower correlation coefficient $(r=0.57, \mathrm{P}<0.01)$ (not

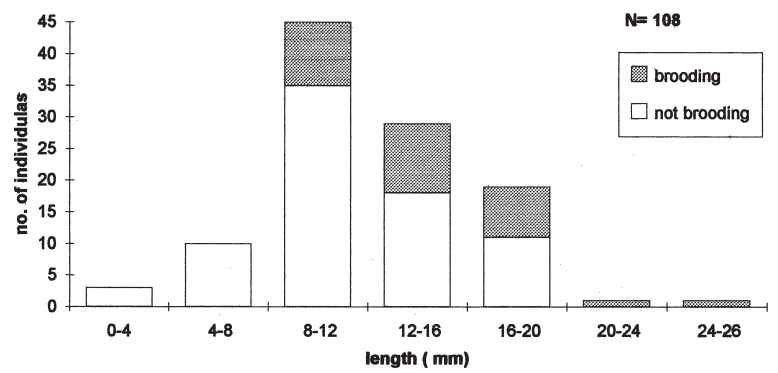

FIG. 2. - Size frequency distribution of brooding and not brooding specimens of the Perkinsiana antarctica population sampled in
October 1994 . 

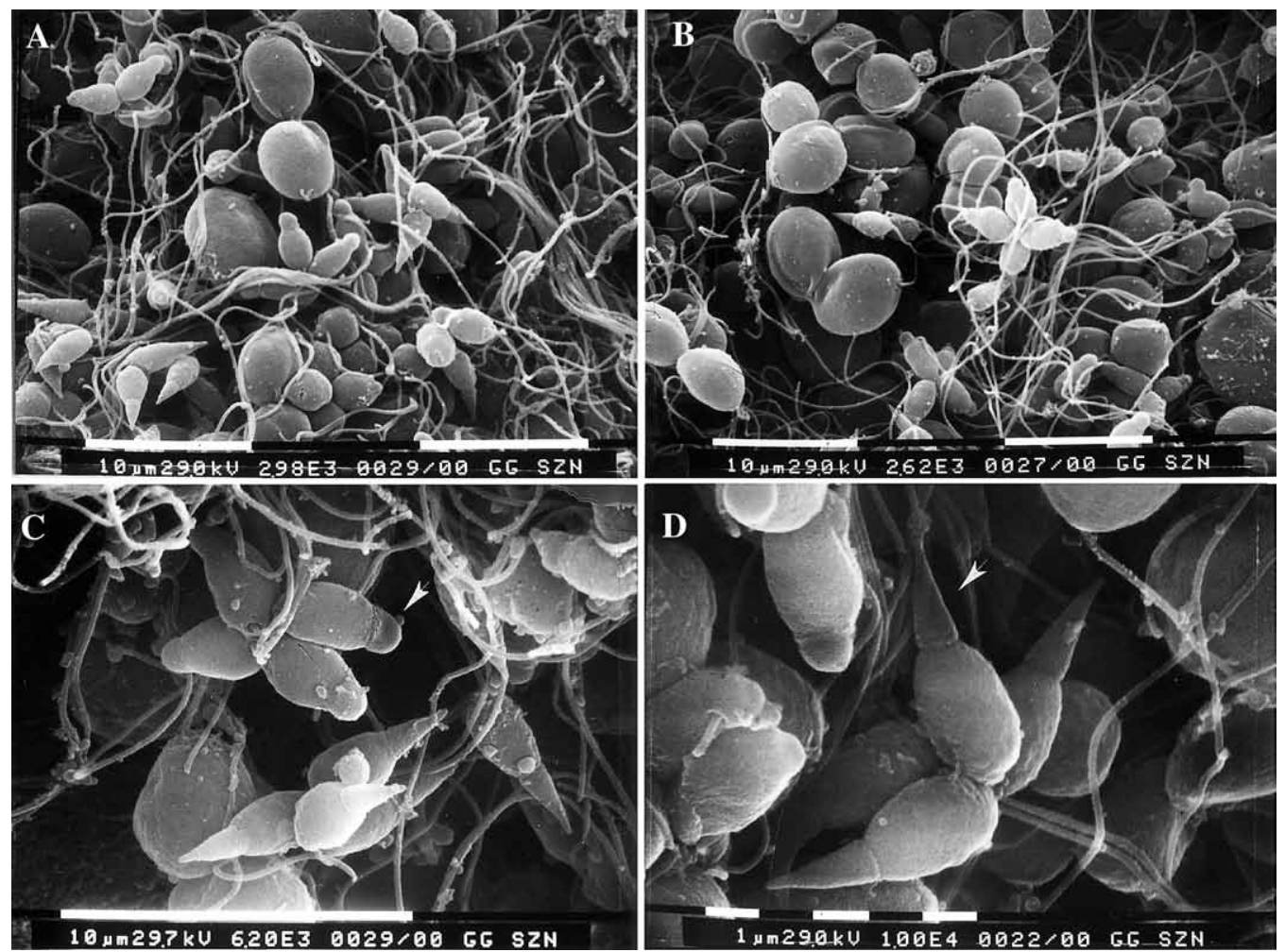

FIG. 3. - Scanning electron (S.E.M.) micrographs of sperm cells of Perkinsiana antarctica at different developmental stages. A and B, groups of spermatogonia and spermatids in the coelomic cavity (about 3,000x). C, early spermatids grouped in tetrads (note the rounded shape of the acrosomes, arrow) (6,000x). D, spermatids grouped in tetrads (note the pointed acrosomes, arrow) (10,000x).

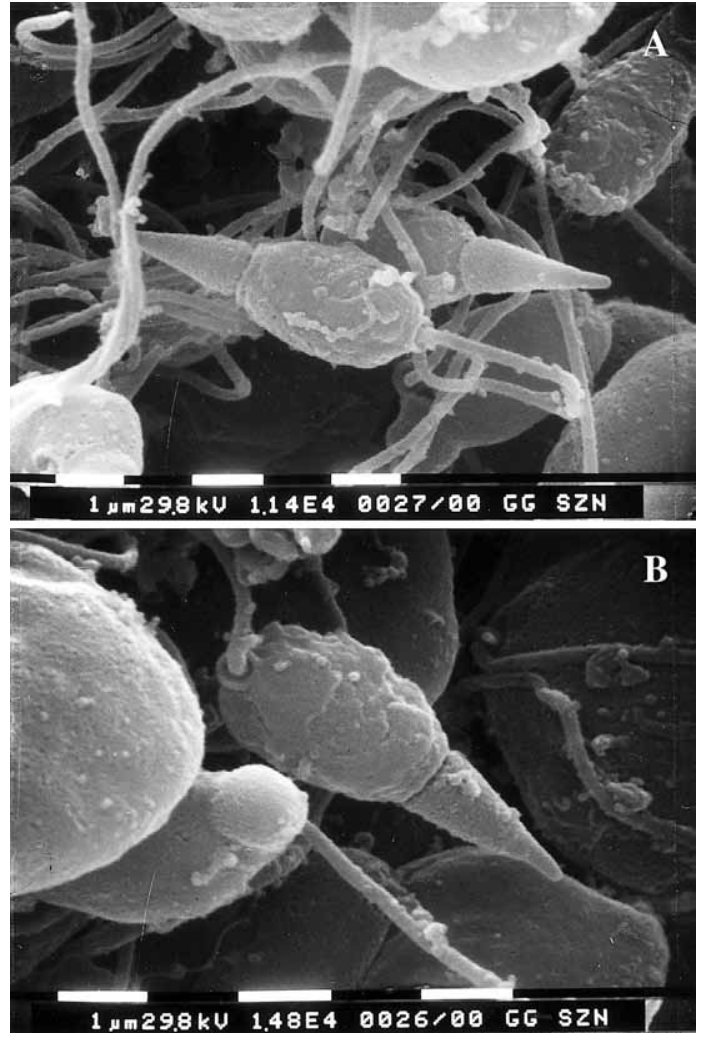

FIG. 4. - A and B, S.E.M. micrographs of mature spermatozoa of $P$. $\operatorname{antarctica}(\mathrm{A}=11,000 \mathrm{x} ; \mathrm{B}=14,000 \mathrm{x})$. shown), while body and crown length were poorly related.

The size frequency distribution of the October 1994 population showed a unimodal pattern, with the modal class at 8-12 mm (Fig. 2). The incubating specimens always exceeded $10 \mathrm{~mm}$ in length (Fig. 2). The length of specimens collected in March 1997 ranged from 2.4 to $35 \mathrm{~mm}$, but the population structure was not estimated since $43 \%$ of the individuals were broken.

$P$. antarctica turned out to be a simultaneous hermaphrodite with eggs present in the thorax and anterior abdomen, and sperm cells at various stages of maturation, mainly in the posterior abdominal part (Fig. $3 \mathrm{~A}$ and B). Egg size (diameter) ranged from 220 to $250 \mu \mathrm{m}$ (mean diameter $=235 \mu \mathrm{m})$. Spermatids are grouped in tetrads (Fig. 3C and D) and present an ovoid dense nucleus. The mid-piece seems quite short (Fig. 4). In the early spermatids the acrosome is still flat and rounded (Fig. 3C), while in mature sperm cells the nucleus has a major axis length of about $3 \mu \mathrm{m}$, and the acrosome is about $2.5 \mu \mathrm{m}$ long with a conoid shape (Fig. 4A and B). Both developing eggs and larvae are incubated among the radioles within the branchial crown, grouped in two lengthened masses and embedded in 

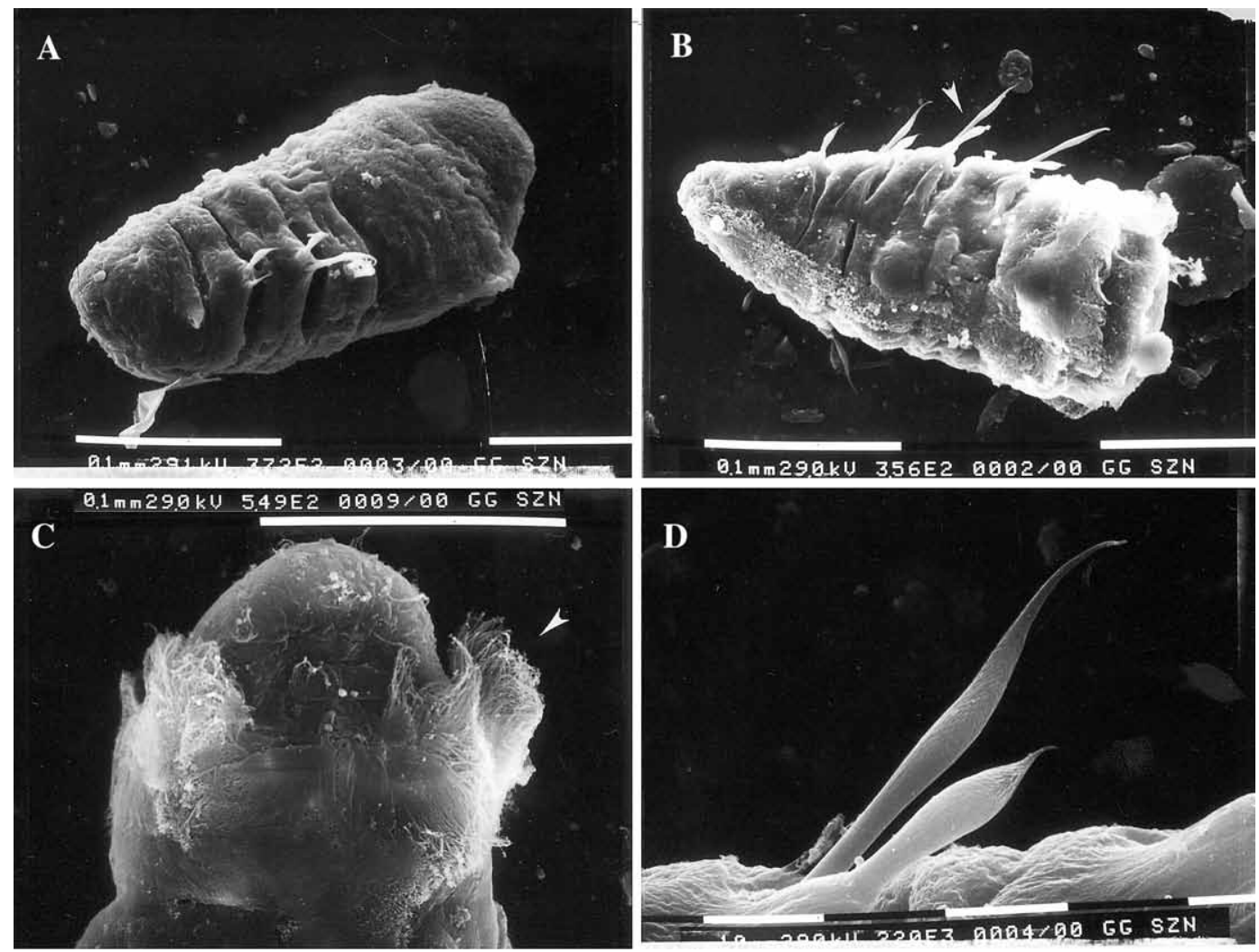

FIG. 5. - A and B, S.E.M. micrographs of brooded larvae of Perkinsiana antarctica hatched with four setigers $(A=3,700 x ; B=3,500 x)$ C, anterior part of a four-setiger larva showing the prototroch $(5,400 \mathrm{x})$. D, particular of hooded and paleate notochaeta of a larval setiger $(22,000 x)$.
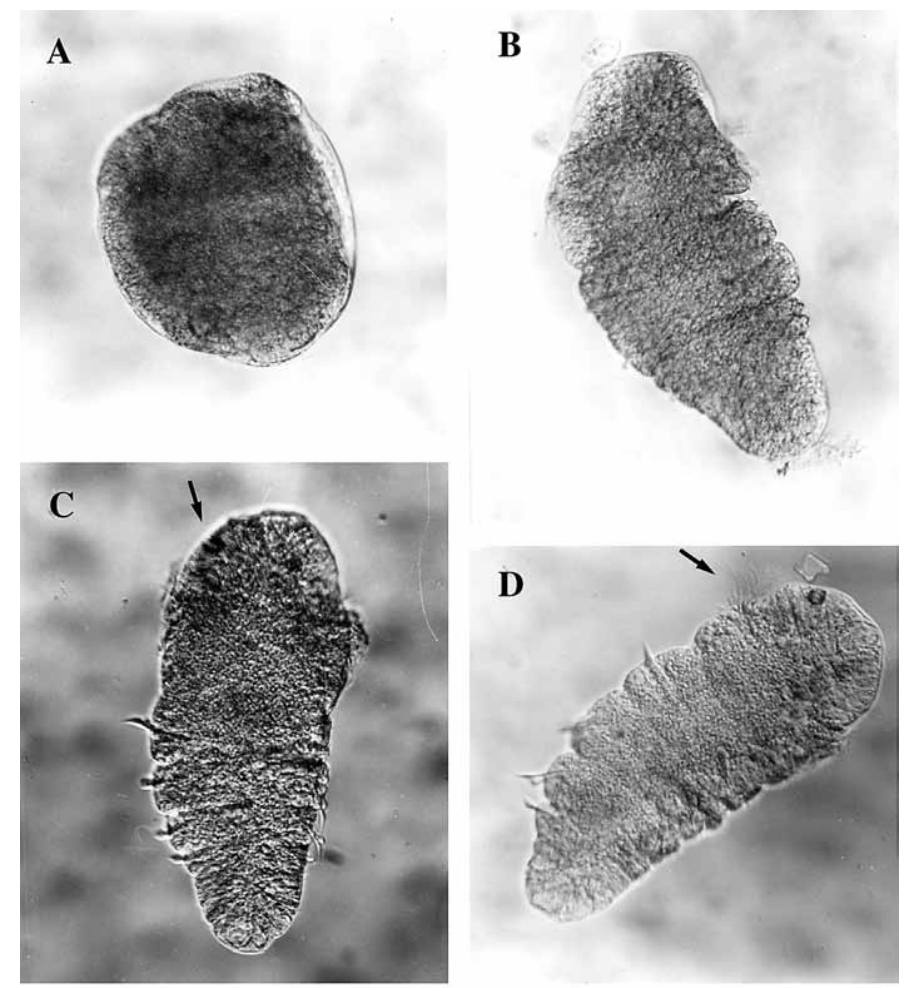

\section{$0.5 \mathrm{~mm}$}

FIG. 6. - Optical microscope photographs of brooded embryos and larvae of P. antarctica. A, developing embryo. B, C and D, hatched foursetiger larvae, note the ocular spots, and the prototroch (arrows in $\mathrm{C}$ and $\mathrm{D}$ ). 
a mucous sheath. This observation is consistent with that of Knight-Jones and Bowden (1984). In the October 1994 population a total of 71 specimens (20\% of the individuals collected) were observed brooding eggs (46) or larvae (25). In the material sampled in March 1997 only 5 specimens (10\%) were observed brooding eggs (4) or larvae (1).

The larvae at hatching are characterized by 3-4 segments and have a mean length of $420 \mu \mathrm{m}$ (Fig. $5 \mathrm{~A}$ and $\mathrm{B})$. In the anterior end of the larva a distinct prototroch is present which forms a well developed ring (Fig. 5C). Anterior to the prototroch two ocular spots are evident (Fig. 6); the branchial crown is not yet developed; the pygidium is rounded. Each larval segment is bearing only one narrowly hooded and one paleate notochaeta (Fig. 5D). Since this is the more advanced developmental stage observed, it cannot be excluded that the larvae may have a short swimming period before settlement and complete the metamorphosis outside the branchial crown of the parent.

Both the number of embryos and larvae per individual showed a relatively high range of variation (embryos from 54 to 374, mean=173; larvae from 18 to 222, mean=101) (Gambi and Patti, 1998).

\section{DISCUSSION}

The finding of $P$. antarctica at Bahia Laredo in two different seasons and within a time-span of a few years, indicates that in this area this species is forming stable populations, locally quite dense and well structured.

The relatively low number of incubating specimens observed in October 1994 suggests that the population was probably in an early phase of the reproductive cycle, while the few incubating specimens collected in March 1997 may indicate that at this time of the season reproduction was probably over. Thus, the higher reproductive effort is probably afforded during the austral summer season.

The sperm morphology observed is intermediate between the typical rounded form of the "ectaquasperm" (considered more primitive and generally associated with free-spawning and external fertilization), and those long, slender and pointed of the "ent-aquasperm" (considered derived and generally associated with internal fertilization) (Jamieson and Rouse, 1989). In a review on the reproductive pattern in Sabellidae, McEuen et al. (1983) already noted that species brooding outside of the tube and of medium size, had spermatozoa to some extent intermediate between primitive and modified types. The sperm ultrastructure is known for two other species of Perkinsiana: P. rubra (Langerhans) and $P$. riwo Rouse. In $P$. rubra the sperm morphology is very similar to that recorded in $P$. antarctica, with ovoid nucleus and acrosome tapering and very elongate (about $8 \mu \mathrm{m}$ in length) (Chugthai, 1986), while in $P$. riwo, which also broods the eggs, the sperm has a rounded and flat acrosome and resembles in its general morphology that of more "primitive" type (Rouse, 1996), as in Pseudopotamilla (Chugthai, 1986) or in Branchiomma (Sordino and Gambi, 1992).

Within the sub-family Sabellinae, $P$. antarctica is together with the co-generic $P$. riwo, the only species incubating the eggs within the branchial crown and showing simultaneous hermaphroditism (Rouse, 1996). However, compared with $P$. riwo and other incubating Sabellidae, P. antarctica is of larger size and produces a higher number of offspring (Rouse, 1996). Previous information on the species (Knight-Jones and Bowden, 1984; Rouse and Fitzhugh, 1994) indicated, in fact, a maximum number of larvae per individual around 150, which is within the range of values estimated in this study. Other species of Perkinsiana, such as P. littoralis and $P$. borsibrunoi which also occur in Antarctic waters, are gonochoric and free-spawners (Gambi et $a l$. , in press). P. milae, recently described from the Ross Sea (Giangrande and Gambi, 1997), showed the interesting feature of asexual reproduction (scissiparity) (Gambi et al., in press). These findings demonstrate the relatively high variability in reproductive features within the genus Perkinsiana, and also the apparent lack of synapomorphies concerning the main reproductive traits. However, analysis of further characters, such as sperm ultrastructure, is in progress. This feature has been demonstrated to be useful to elucidate the presence of common traits of reproduction, and has already been used for other sabellids (Rouse, 1995).

In conclusion, the features of reproductive biology in $P$. antarctica do not seem related to the size of the species itself, as $P$. antarctica represents one of the larger-sized sabellids brooding the eggs, nor to other phylogenetic constraints. These traits seem more related to the environment and have probably favoured the colonization of intertidal and shallow subtidal areas of the Subantarctic. Brooding and direct development, in fact, are often present in intertidal or brackish water invertebrates, despite the 
fact that this habit is considered one of the $\mathrm{K}$-selected traits of the life history. In harsh and/or highly fluctuating environments distribution and population size of the living organisms are also highly variable. The brooding habit seems to promote in these habitats a fast recovery of the population from relatively few surviving adults (Giangrande et al., 1994).

\section{ACKNOWLEDGEMENTS}

This research was carried out in the framework of the "Progetto Magellano" funded by the Italian "Programma Nazionale di Ricerche in Antartide" (P.N.R.A.). Thanks are due to G. Procaccini and M.B. Scipione (Stazione Zoologica di Napoli) for collection of samples in the Strait of Magellan during the "Victor Hensen" campaign, and to Prof. W. Arntz (Alfred Wegener Institute, Germany) for campaign organization and logistic support. We wish to thank also E. Mutschke and C. Ríos (Instituto de la Patagonia, Chile) for providing the specimens of $P$. antarctica collected at Bahía Laredo in March 1997. Prof. V. Storch and Dr. B. Hilbig kindly read the paper and corrected the English.

\section{REFERENCES}

Arntz, W.E. and M. Gorny. - 1996. Cruise report of the joint Chilean-German-Italian Magellan "Victor Hensen" Campaign in 1994. Ber. Polarforsch., 190: 1-113.

Brey, T., C. Dahm, M. Gorny, M. Klages, M. Stiller and W.E. Arntz. - 1996. Do Antarctic benthic invertebrates show an extended level of eurybathy? Antarct. Sci., 8(1): 3-6.

Chugthai, I. - 1986. Fine structure of the spermatozoa in Perkinsiana rubra and Pseudopotamilla reniformis (Sabellidae: Polychaeta). Acta Zool., 67 (3): 165-171.

Gambi, M.C., G. Procaccini and M.B. Scipione. - 1996. Plant-animal relationships in the intertidal and shallow subtidal areas of the Strait of Magellan. In: W. Arntz and M. Gorny (eds.), Cruise report of the joint Chilean-German-Italian Magellan "Victor Hensen" Campaign in 1994. Ber. Polarforsch., 190: 75-78.

Gambi, M.C. and F.P. Patti. - 1998. Observations on reproductive biology of Perkinsiana antarctica (Kinberg) (Polychaeta, Sabellidae). Biol. Mar. Medit., 5 (1): 336-338.

Gambi, M.C., A. Giangrande and F.P. Patti. - in press. Comparative observations on reproductive biology of four species of Perkinsiana (Polychaeta, Sabellidae). Bull. Mar Science.

Giangrande, A., G. Belmonte and S. Geraci. - 1994. Life cycle and life history traits diversity in marine invertebrates and implications in community dynamics. Oceanogr. Mar. Biol.: Ann. Rev., 32: 305-333.

Giangrande, A. and M.C. Gambi. - 1997. The genus Perkinsiana (Polychaeta, Sabellidae) in Antarctica, with the description of two new species, P. milae and P. borsibrunoi. Zool. Scripta, 26 (3): 267-278.

McEuen, F. S., B.L. Wu and F.S. Chia. - 1983. Reproduction and development of Sabella media, a polychaete with extratubular brooding. Mar. Biol., 76: 301-309.

Jamieson, B.G.M. and G.W. Rouse. - 1989. The spermatozoa of the Polychaeta (Annelida): an ultrastructural review. Biol. Rev., 64: 93-157.

Knight-Jones, P. and N. Bowden. - 1984. Incubation and scissiparity in Sabellidae (Polychaeta). J. mar. biol. Assoc. U.K., 64: 809-818.

Pearse, J.S., J.B. McClintock and I. Bosch. - 1991. Reproduction of antarctic marine invertebrates: tempos, modes, and timing. Amer. Zool., 31: 65-80.

Rouse, G.W. - 1995. Is sperm ultrastructure useful in polychaete systematics? An example using 20 species of the Fabriciinae (Sabellidae, Polychaeta). Acta Zool., Stockholm, 76: 57-74.

Rouse, G.W. - 1996. A new species of Perkinsiana (Sabellidae, Polychaeta) from Papua New Guinea; with the description of larval development. Ophelia, 45(2): 101-114.

Rouse, G.W. and K. Fitzhugh. - 1994. Broadcasting fables: Is external fertilization really primitive? Sex, size and larvae in sabellid polychaetes. Zool. Scripta, 23: 271-312.

Sordino, P. and M.C. Gambi. - 1992. Prime osservazioni su biologia riproduttiva e sul ciclo vitale di Branchiomma luctuosum (Grube, 1869) (Polychaeta, Sabellidae). Oebalia, suppl. 17: 425-427. 